cordierite, a decrease in the latter is to be accompanied with an increase in the former. In the present case the percentage of magnesia is also low. The ferrous equivalent of the sum of ferrous oxide and magnesia does not fall below 22 per cent in the analyses given by Dana, while it is as high as 27 per cent in the case of Finland cordierite. The percentage of alumina usually does not go berond 33 , whereas in the present case it is as high as $35 \cdot 2$. The other constituents remain within normal limits. If we may rely on the accuracy of this analysis, this cordierite is of a peculiar constitution. It must, however, be remembered that there is just a possibility of error in the determination of the two oxides of iron.

The positive character of some of these cordierite crystals is confirmed by the observations of Mr. G. dep. Cotter, Assistant Superintendent, Geological Survey of India. His remarks on the mineral are given below :-

"In the slide which Mr. Chacko now sends I find that one section of cordierite gives a positive figure and one section gives a negative figure. I have also found a positive figure from the cordierite from Vizagapatam, 16/189. This is probably due to the increase of the value of $2 \vec{V}$ beyond $90^{\circ}$ (see Iddings). $2 V$ in cordierite is very variable, and the lower the refractive the greater is $2 V$. The mineral sent now by Mr. Chacko has been tested by the method of Schroeder Van der Kohlk, and its refractive index lies between nitrobenzene and cedar oil, and it gives reds and blues for a mixture of both. Therefore its refractive index is about 1.53 , that is, fairly low. We may then conclude that $2 V$ is probably large. In fact, I agree with what Mr. Chacko suggests, and think it might be worth publishing if he cares to do so. There is no section in the slide suited to the actual measurement of $2 F . "$

\title{
INOTIOFS OF MEMOIRS.
}

I.-British Association for the Advancement of Science, Eightysixth Anndal Meeting, Newcastle-dpon-Tyne, Shpiember 6-8, 1916.

List of Authors and Titles of Papers read in Section C (Geology). Presidential Address by Professor $W$. S. Boulton.

Professor G. A. Lebour.-Address on the Local Geology.

Dr. D. Woolacott. - Some Notes on the Permian of Durham.

Dr. G. Hickling.-Underground Contours of the Black Mine.

Professor W. G. Fearnsides.-Underground Contours of the Barnsley Mine.

Joint Meeting with Section $\mathrm{E}$ in the Room of Section C.

Dr. A. Wilmore.-The Physical Geography and Geology of the Northern Pennines.

Professor W. G. Fearnsides and Dr. P. G. H. Boswell.-Note on the Occurrence of Refractory Sands and Associated Materials occurring in Hollows in the Surface of the Mountain Limestone District of Derbyshire and Staffordshire.

Dr.P. G. H. Boswell.-Geological Characters of Sands used in Glass Manufacture. 
Reports of Research Committees :-

Dr. $W . T$. Gordon.-Report of Committee to investigate the Flora of Lower Carboniferous times as exemplified at a newly discovered locality at Gullane, Haddingtonshire.

Professor T. Johnston.-The Old Red Sandstone Rocks of Kiltorcan, Ireland.

Dr. W. Mackie and Dr. J. Horne.-Report of Committee to excavate Critical Sections in Old Red Sandstone Rocks at Rhynie, A berdeenshire.

Dr. R. Kidston, F.R.S. and Professor W. H. Lang, F.R.S.Description of a new fossil plant, Rhynia Gwynne-vaughani found at Rhynie.

Joint Meeting with Section B in the Room of Section C.- On the investigation of the chemical and geological characters of different varieties of coal, with a view to their most effective utilization as fuel, and to the extraction of by-products.

Discussion opened by Professor $G$. $A$. Lebour; and followed by Professor W. A. Bone, F.R.S., Dr. A. Strahan, F.R.S., Dr.J.T. Dunn, and others.

MIr. Joseph Lomax.-Microscopical Examination of Coal as a means of Identification and Correlation of Seams.

Mr. Leonard Hawkes.-The Acid Rocks of Iceland.

Dr. Alexander Scott.-The Petrology of the Arran Pitchstones.

Dr.J.W. Evans.-Methods of representing Geological Formations and Structures in black and white on Maps.

Mr. Leonard Harokes. - The Acid Rocks of Iceland.

Dr. Alexander Scott. - The Petrology of the Arran Pitchstones.

$E$. Heron-Allen.- The Application of $\mathrm{X}$-rays to the Determination of the internal Structure of Microscopic Fossils, especially with regard to the Dimorphism of the Nummulites.

Professor W. W. Watts, F.R.S.-Geological Photographs.

\section{Papers read in other Sections bearing on Geology.}

\section{Section D.-Zoologr.}

Professor A. Meek.-The Scales of Fishes and their value as an aid to investigation.

\section{Section E.-Geography.}

Dr. W. S. Bruce.-The Weddell Sea.

\section{Section H.-ANTHRopology.}

Professor W. J. Sollas, F.R.S.-A Sub-Crag Flint Implement.

Dr. Marrett.-Recent Archæological Discoveries in the Channel Islands.

\section{Section K.-Botany.}

Joint Meeting with Section $\mathrm{C}$ in the Rooms of Section $\mathrm{K}$ (Botany).

Discussion on the bearing of Botanical Science on Coal, to be opened bs Dr. Marie C. Stopes.

Professor $R$. H. Yapp. - The Origin of Salt-marsh Pans. DECADE VI.-VOL. III.-NO. $\mathrm{x}$. 
Discussion on the Utilization of Waste Lands, introduced by Professor $F$. W. Oliver, and including the following short papers:-

P. A. Martineau.-The Afforestation of Pit Banks: Discussion.

Professor F. W. Oliver.-Maritime Wastes.

Professor W. B. Bottomley.-Waste Moorlands.

Professor $J$. Lloyd Williams.-Reclamation of Peaty Soils in Carnarvonshire.

Dr. W. G. Smith.-Utilization of Northern Mountain and Heath Land.

II.-Some Grological Characters of Sands osed in Glass Manufacture. By P. G. H. Boswell, A.R.C.Sc., D.Sc., F.G.S.

$\mathrm{T}$ a time when it is necessary to know the extent and value of A our national resources of sands suitable for various industrial purposes, including glass manufacture, it is especially desirable that we should realize the particular properties of such sands and the geological conditions under which the deposits occur in the field.

1. In chemical composition, for all general purposes of glassmaking, the sand should contain a very high proportion of silica, if possible over 99 per cent. The percentage of iron (estimated at $\mathrm{Fe}_{2} \mathrm{O}_{3}$ ) should be as low as possible. For optical glass, table-ware ('crystal'), etc., it should not rise above 0.5 per cent ; for laboratoryware, globes, and all second-grade glass-ware, a percentage up to 0.02 is permissible; for plate and window-glass and good white bottle-glass, the proportion may reach 0.3 or 0.4 per cent; and for rough bottle-glass and other similar work, a limit of 2 per cent may be admitted. For refractory glass, such as that used for thermometers, gauges, certain laboratory-ware, etc., it is an adrantage to find a sand bearing 4 per cent or more of alumina. Unfortunately, most British sands bearing alumina carry also iron and other undesirable impurities. Other bases such as lime, magnesia, titanium, and alkalies, should, if present at all, exist only in negligible quantities. In the analyses the loss on ignition should also appear; it yields an indication of the amount of water and organic substances present. The latter are not objectionable as they usually 'burn out'.

The analysis of one of the best British glass-sands, a sample of Lower Greensand from Aylesbury, indicates $\mathrm{Si}_{2}, 99 \cdot 80$ per cent; $\mathrm{Al}_{2} \mathrm{O}_{3}, 0.32$ per cent; $\mathrm{Fe}_{2} \mathrm{O}_{3}, 0.03$ per cent; loss on ignition, 0.22 per cent; total, 100.37 per cent. With this may be compared a well-known German glass-sand from Lippe: $\mathrm{Si}_{2}, 99.88$ per cent; $\mathrm{Al}_{2} \mathrm{O}_{3}, 0.18$ per cent; $\mathrm{Fe}_{2} \mathrm{O}_{3}, 0.02$ per cent; loss on ignition, 0.21 per cent; total, $100 \cdot 29$ per cent.

2. For all but the highest quality glass, where the cost of crushing the raw material to a fine even state, with suitable subsequent treatment, is not prohibitive, the mechanical composition is of the utmost importance. The sand used should, if possible, be perfectly graded, that is, it should be composed of grains all of the same size. Such perfection of grading is not attained as a result of natural agencies; the best-graded natural deposits contain over 90 per cent of grains of one grade, which, for glass-making purposes, is preferably 
the medium-sand grade (diameter $>\frac{1}{4}$ and $<\frac{1}{2} \mathrm{~mm}$.). A high percentage of the fine-sand grade (diameter $>\frac{1}{4}$ and $<\frac{1}{10} \mathrm{~mm}$.) would be even more preferable, but suitable sands with a high proportion of this grade are not of common occurrence in this country. Coarser sand. grains are not desirable, and, if present, should be removed by sieving. Very fine sand, silt, and clay-grades are inimical, and must be removed by washing.

3. The mineral composition should be as simple as possible, contain only quartz, or quartz and felspar, and the heavy detrital minerals present should be small in quantity and simple in composition.

The treatment of sands (whether chemical, to remove iron, or mechanical, to ensure good grading) often involves prohibitive expense. It is therefore of considerable importance to look into the geological conditions under which desirable glass-sands occur. We may thus receive clues to the existence of further supplies by knowing the kind of deposits in which they are met, and the special conditions under which we may expect to find them. The important supplies of glass-sands occurring in Western Europe are associated with rafts of braunkohle in beds of Miocene age; Hohenboka sand, of the same age, containing carbonaceous layers; Fontainebleau sand, in Upper Oligocene deposits, with lignites; Inferior Oolite sands in the Yorkshire and Northampton districts, containing planty matter and roots; Berrythorpe sand (Callovian), containing carbonized woody material and peaty matter; Aylesbury and Leighton Buzzard sands (Lower Greensand) with peaty bands; Headon Hill and Bagshot. from Alum Bay, Wareham, and other places (Eocene, etc.), interbedded with lignites. Numerous other examples may be adduced. Attention also may be drawn to the very pure sandstones of the Coal-measures, associated with coal-seams, and to the white sandstones found with the Brora coals of Scotland (Callovian). The bleaching of the reddish sands, for a foot or two in depth, upon our heaths, is a similar phenomenon. In each case the freedom from iron may be attributed to the reducing action of the planty matter, in changing the ferric salts to the more soluble ferrous state, when they are more easily removed by percolating waters.

The beds of white sand seem always to be of limited thickness, and frequently to be laid down under lagoon or estuarine conditions favouring the development of plant life. Cementation is objectionable, either because of the introduction of impurities or because of the cost of subsequent crushing. It is desirable, therefore, that the deposits should be incoherent. The most widely used sands are thus those of comparatively late geological age. Most of them occur in Tertiary deposits, but some are Cretaceous in age. A strong tendency, also, exists for the simplification in mineral constitution (due to elimination of more easily decomposable minerals) and greater perfection of grading in the later geological sediments-a result of their constituents having passed through many geological cycles.

[This, and the two following Notices, are Abstracts of papers read in Section C (Geology), British Association, Newcastle-on-Tyne, September, 1916.] 


\section{Notices of Memoirs-L. Hawkes-Rocks of Iceland.}

\section{III.-Thr Acid Rocks of Iceland. By Leonard Hawres, M.Sc.}

$A$ account was given of the preliminary results of an investigation widely developed in East Iceland, but hitherto definite information as to their extent, nature, and mode of occurrence has been lacking. Whilst they have been stated to be partly intrusive and partly extrusive, ${ }^{1}$ it has generally been accepted that they are dominantly intrusive in character, ${ }^{2}$ a view which has probably been influenced by the general intrusive nature of the British Tertiary acid rocks. ${ }^{3}$

The main exposures of acid rocks in East Iceland from Borganfjord to Bernfjord have been studied in the field. Evidence was brought forward to show that these rocks are in the main extrusive in character. In places the acid series is at least 2,000 feet in thickness. Tuffs and sphærolitic liparites and obsidians are very common. The author holds that the old view, that the acid rocks are dominantly intrusive, being thus marked off from the basic rocks, is incorrect. Tertiary volcanic activity was similar to that which has obtained in Iceland in post-Glacial times, when acid rocks have been extruded along with the basic, but in a smaller amount. Acid eruptions seem to have taken place almost continuously during the building up of the 'lertiary plateau. The uneroded character of the liparite lavastreams shows how rapidly the successive basalts which submerge them were poured out, and this throws some light on the problem of the intrusive or extrusive origin of the Antrim rhyolites.

Since the close of the Tertiary volcanic period enormous denudation has obtained, and the varying resistance offered to erosive agents by acid and basic rocks has produced some remarkable effects.

Thoroddsen has described some peculiar streams of acid rocks which he regards as post-Glacial lava-flows, formed by the extrusion of liparite blocks in a half-melted condition from the mountain sides. The most noteworthy of these occurs in the Lodmundarfjord. The rocks of the district are Tertiary bedded basalts with the exception of an acid series, contemporaneous with the basalts, revealed in a huge cirque excavation in a side valley. The valley is full of a chaotic assemblage largely composed of sphærolitic liparite reaching down from the cirque (Skúmhöttur) on the bottom of the main valley (Lodmundarfjord).

The author holds that these blocks do not represent a lava-stream but a moraine. All the rocks of the stream occur in situ in the Skúmhöttur mountain. The theory of morainic origin has been previously rejected, partly on account of the reported exclusive liparite composition, where a mixture of acid and basic rocks would have been expected. It was found, however, that the stream is not exclusively composed of acid types, though dominantly so. The

I Th. Thoroddsen, "Island: Grundriss der Geographie und Geologie," No. 152 : Pet. Mitt., 1905, p. 269.

2 Ibid., p. 232. H. Pjeturss, "Island": Handbuch der Regionalen Geologie, 1910, p. 5. C. W. Schmidt, "Der Liparite Islands in geologischer und petrographischer Beziehung": Zeit. Deutseh. geol. Ges., vol. xxxvii, p. $783,1885$.

${ }^{3}$ Sir A. Geikie, Ancient Volcanoes of Great Britain, vol, ii, p. 364, 1897. 
large proportion of liparite present results from its lesser resistance to ice-erosion compared with basalt, whereby the huge cirque has been excavated where the acid rocks occur, and the material deposited to form the present remarkable stream. It has also been objected that none of the blocks are ice-scratched, but this is not to be expected owing to the exceptional fissility of liparite and its rapid degradation under weathering influences. The author has never seen an ice-scratched boulder in Iceland.

IV.-The Petrology of the Arran Pirchstones. By Alexandre Scotr, M.A., D.Sc.

LTHOUGH the Arran pitchstones are so widely known, no A extensive examination of them has ever been made. The intrusions, which number about eighty, may be divided into the following groups:-

1. Non-porphyritic glasses with abundant microlites which are generally hornblende. These are found chiefly in the district round the coast, and include the Corriegills and Monamore Glen occurrences.

2. Pitchstone porphyries with large phenocrysts of quartz and felspar and scarce augite, and with hornblende microlites. This group includes many of the dyke-rocks intrusive into the Goatfell granite.

3. Pitchstone porphyries with phenocrysts of felspar and pyroxene and subordinate quartz. The pyroxene includes both augite and enstatite, and scarce crystals of an iron-rich olivine also are found. Microlites of pyroxene and of hornblende occur: This group is typical of the intrusions of the south end of the island.

4. More basie type with scarce phenocrysts and great abundance of pyroxene microlites. This group is represented by two occurrences in Glen Cloy and several around the great Tertiary volcanic vent.

Analyses have been made of each type, and the results show the existence of considerable variation in composition. An attempt has been made to determine the cooling histories from the examination of the field-relations and microscopic structures of the various types, and also to indicate the conditions which are responsible for such a large development of glassy intrusive rocks.

\section{I.-The Later Stages of the Evolditon of the Ianfous Rocks.} By N. L. Bowen. Journ. Geol,, Supp. to vol. xxiii. pp. 91. 1915.

I THE determination of the processes whereby the rarious types of igneous rock have been derived by differentiation from a few relatively simple magmas has long been, and still is, one of the chief problems of petrology. Of the hypotheses which have been advanced in order to explain differentiation, several have been discredited and are seldom advocated nowadays; thus "Soret's principle", to which 